\begin{tabular}{|c|c|c|c|}
\hline UNIVRS & $\begin{array}{l}\bullet: 1: m \\
\text { HASA }\end{array}$ & $\begin{array}{l}\text { Journal of } \\
\text { English Language Teaching } \\
\text { Innovations and Materials }\end{array}$ & 0 \\
\hline $\begin{array}{l}\text { Article received } \\
\text { Article accepted } \\
\text { Published }\end{array}$ & $\begin{array}{l}: 16^{\text {th }} \text { March } 2020 \\
: 17^{\text {th }} \text { March } 2020 \\
: 16^{\text {th }} \text { April } 2020\end{array}$ & & $\begin{array}{c}\text { Vol. 2(1) } \\
\text { April } \\
2020\end{array}$ \\
\hline
\end{tabular}

\title{
Teaching grammar: issues and challenges
}

\begin{tabular}{c} 
Norhaida Aman \\
English Language and Literature Academic Group, National Institute of Education, Nanyang \\
Technological University, Singapore \\
norhaida.aman@nie.edu.sg \\
Invited Article \\
\hline DOI: http://dx.doi.org/10.26418/jeltim.v2i1.40032
\end{tabular}

\begin{abstract}
The relationship between teachers' beliefs and their instructional practices has attracted educational researchers' attention. The literature on teachers' beliefs and classroom practices suggests that a sound understanding of those beliefs is extremely helpful in developing and implementing useful programs and effective in-service training. This study explores the complex relationship between the beliefs and practices of teachers from primary schools in Singapore, specifically looking at how instructional strategies are reflections of teacher beliefs on grammar instruction.
\end{abstract}

Overall, the teachers who participated in this survey unanimously agree that grammar is important and has to be taught in primary school. They believe that grammar consists of rules of sentence formation, and the use of accurate tenses, and that grammar should focus on both form and meaning. Explicit discussion of grammatical rules in the classroom is thought to be extremely important in helping students acquire the English language and develop their writing skills.

In terms of their classroom practices, the data suggests a more traditional approach of explicit teaching of grammar where rules and sentence structures are first taught to students and brought to their attention.

Keywords: grammar teaching; grammar instruction; teacher beliefs

How to cite this paper: Aman, N. (2020). Teaching grammar: issues and challenges. Journal of English Language Teaching Innovations and Materials (JELTIM), 2(1), 1-13. DOI: http://dx.doi.org/10.26418/jeltim.v2i1.40032 
There is an extensive body of research which looks at the complex relationship between teachers' beliefs and their instructional practices. The literature on teachers' beliefs and their classroom practices suggests that a good understanding of those beliefs is extremely helpful in developing and implementing effective pre-service and in-service programmes (Richardson, Anders, Tidwell and Lloyd, 1991).

Teachers' pedagogical beliefs on how students learn and what type of instructions are best suited for deep learning are considered as major determinants of the choices teachers make in the classroom concerning curriculum, pedagogy, assessment, and classroom management (Orton, 1996; Vartuli, 1999; Pajares, 1992; Aman 2016). However, even if the prima facie connection between beliefs and classroom practices may seem obvious, teachers' beliefs can be difficult to capture and many not be consistent with their practices (Kagan 1992). According to McMullen (1999), this discrepancy could be due to a variety of reasons: environmental, work-related stress or institutional barriers.

Despite this, research has largely shown that what teachers eventually choose to employ in their classrooms largely depended on a number of things the type of training they received, their subject knowledge, and their beliefs on classroom instruction and their beliefs about their students' abilities and interests (Aljohani, 2012; Aman, 2016; Canh \& Barnard, 2009).

With regard to grammar instruction, grammar could be taught in a variety of ways:

(i) via explicit teaching where rules are clearly brought to the students' attention,

(ii) via implicit teaching where rules are not pointed out, but understood implicitly through a variety of stimulus and different forms of exposure,

(iii) using a deductive approach where the rules are first told to the students,

(iv) using an inductive approach where students identify the patterns on their own by examining a number of examples,

(v) separately, where grammar rules are taught in isolation, or

(vi) integratedly, where grammar is taught together with other learning activities.

According to Borg (2003), studies on teacher cognition and beliefs can include teachers' self-evaluated knowledge about grammar, their beliefs about grammar instruction, and their self-report classroom practices. There are previous studies that have investigated Singapore teachers' beliefs and classroom practices in secondary schools (Ng, 2012; Ng \& Farrell, 2003). Others have carried out small-scale studies involving primary school teachers (Chia, 2003; Farrell \& Lim, 2005).

Journal of English Language Teaching Innovations and Materials (JELTIM), 2(1), 1-13

Copyright ( 2020 by JELTIM, e-ISSN 2657-1617 
This study aims to target a bigger and more representative sample of primary school teachers in Singapore. It is meant to collect a baseline survey of primary school teachers' attitudes towards grammar and their beliefs regarding grammar instruction - whether they prefer the traditional approach which includes explicit, deductive grammar teaching followed by repetitive drill and practice, or if they value teaching grammar indirectly through communicative activities that develop students' linguistic proficiency via the extensive use of the language. Also important is the question of whether teachers tend to focus more on grammatical forms and less on use in meaningful context. This study also aims to identify some of the problems and challenges faced by the teachers in developing and implementing meaningful and interesting English grammar lessons.

\section{METHODOLOGY}

This was largely a quantitative study. The data collection consisted of a 70-item survey with questions pertaining to

- teacher beliefs on the importance of grammar instruction,

- their subject knowledge

- their classroom practices, and

- the challenges they face in teaching and assessing grammar.

A 5-point Likert scale rating was used, ranging from 'strongly agree/always' to 'strongly disagree/never'. The survey also included a few open-ended questions.

The initial target group was 100 primary school English teachers. An email was sent to a group of teacher-leaders, inviting them and their teachers to participate in the online survey. They were informed that they could respond to the survey anonymously. Data collection was carried out using an online survey software: Survey Monkey. At the end of two months, 81 teachers completed the survey in its entirety. The quantitative data was later analyzed using Statistical Software for Social Sciences (SPSS).

\section{Demographic Profile of the Teachers}

Out of the 81 teachers who completed the survey, 29 of them $(35.8 \%)$ held leadership positions in school as Heads of Department, Lead Teachers, Senior Teachers \& Level Heads, as seen in Table 1: 
Table 1. Teachers' current position in school $(\mathrm{N}=81)$

\begin{tabular}{lll}
\hline Teachers' Position & Frequency & Percent \\
\hline Head of Department & 5 & 6.2 \\
\hline Lead Teacher & 1 & 1.2 \\
\hline Senior Teacher & 8 & 9.9 \\
\hline Level Head & 15 & 18.5 \\
\hline Teacher & 43 & 53.1 \\
\hline Beginning Teacher & 3 & 3.7 \\
\hline Others & 4 & 4.9 \\
\hline No Response & 2 & 2.5 \\
\hline Total & 81 & 100.0 \\
\hline
\end{tabular}

The teachers were also asked about their highest level of qualification, specifically in teacher training. $8.6 \%$ of the 81 respondents had a Certification in Education; $22.2 \%$ of them had a Diploma in Education; $28.4 \%$ of them had a Bachelor of Art (Education) or Bachelor of Science (Education); and another $28.4 \%$ of them had a Postgraduate Diploma in Education. 8.6\% of them had a Master degree in Education.

Table 2. Teachers' highest level of teacher training/education $(\mathrm{N}=81)$

\begin{tabular}{lll}
\hline & Frequency & Percent \\
\hline Certificate in Education & 7 & 8.6 \\
\hline Diploma in Education & 18 & 22.2 \\
\hline $\begin{array}{l}\text { Bachelor of Art (Education) / } \\
\text { Bachelor of Science (Education) }\end{array}$ & 23 & 28.4 \\
\hline Postgraduate Diploma in Education & 23 & 28.4 \\
\hline Master of Education & 7 & 8.7 \\
\hline Others & 2 & 2.5 \\
\hline No Response & 1 & 1.2 \\
\hline
\end{tabular}

In Singapore, most primary schools teachers have to teach two or more subjects. 35.8\% of the respondents (29 out of 81 ) taught only English. 34.6\% of the respondents taught English and another subject. 23.5\% of them taught English and another two subjects, and $4.9 \%$ of them taught English and another three subjects.

The number of subjects teachers are required to teach may have an effect on their subject mastery as well as their opportunities for professional development training. This means that for the majority of the teachers, the professional development opportunities which allow them to upskill their subject content knowledge will have to be split between English and at least one other subject. In a separate question on when they last attended a course on English grammar, only about $60 \%$ of them indicated that they had attended one since 2010. This was the year when the national EL syllabus began to place a 
greater emphasis on grammar teaching and learning compared to the previous syllabuses. What this could mean is that a sizeable number of teachers might not have adequate subject knowledge to effectively plan and execute their grammar lessons.

\section{FINDINGS AND DISCUSSION}

\section{Teachers' Beliefs about Grammar}

A set of questions was included in the survey to find out what the teachers thought about grammar in general. Based on a scale of 5 for 'Strongly Agree' to 1 for 'Strongly Disagree', from Table 3, it is evident that teachers unanimously agreed strongly that grammar is important and has to be taught in primary school. They also believed that grammar consists of rules of sentence formation, and the use of accurate tenses, and that grammar should focus on both form and meaning.

Table 3. Teachers' beliefs about grammar $(\mathrm{N}=81)$

\begin{tabular}{|c|c|c|c|c|}
\hline & Minimum & Maximum & Mean & SD \\
\hline $\begin{array}{l}\text { 1. Grammar is important and has to be } \\
\text { taught. }\end{array}$ & 4 & 5 & 4.80 & .401 \\
\hline $\begin{array}{l}\text { 2. Grammar consists of rules of sentence } \\
\text { formation. }\end{array}$ & 2 & 5 & 4.46 & .653 \\
\hline $\begin{array}{l}\text { 3. Grammar focuses on both form and } \\
\text { meaning. }\end{array}$ & 3 & 5 & 4.54 & .593 \\
\hline 4. Grammar is the accurate use of tenses. & 1 & 5 & 4.15 & .943 \\
\hline $\begin{array}{l}\text { 5. There should be more emphasis on } \\
\text { grammar in the syllabus. }\end{array}$ & 2 & 5 & 4.23 & .826 \\
\hline
\end{tabular}

The high mean scores suggest an overall high agreement with the statements in Table 3. However, it is interesting to note that for items 2, 4 and 5, there were big differences between the minimum and maximum scores. The high standard deviation scores suggest a few of the teachers believed that grammar is not merely a set of rules and not about tenses. Also, while the teachers generally felt that there was room for the inclusion of more grammar concepts and lessons in the current syllabus (mean 4.23), the standard deviation of .826 suggests that a few teachers did not agree with this statement.

\section{Grammar as Rules: Linking Beliefs to Practices}

The teachers believed that explicit discussion of grammatical rules in the classroom is crucial to helping students acquire the language and to developing 
their writing skills. Grammatical accuracy is expected of the students and this could be developed through frequent practice, constant feedback, and correction of errors. Teachers then play an important role in providing reinforcement and correcting mistakes made by students as shown by the data in Table 4 .

Table 4. Teachers' beliefs about the importance of grammatical rules $(\mathrm{N}=81)$

Mean SD

\begin{tabular}{lcc}
\hline 1. Explicit discussion of grammatical rules is helpful students. & 4.21 & .802 \\
\hline 2. Teaching grammatical rules aids language acquisition. & 4.25 & .662 \\
\hline $\begin{array}{l}\text { 3. Students need to know grammar rules and how to apply them in their } \\
\text { writing. }\end{array}$ & 4.54 & .653 \\
\hline $\begin{array}{l}\text { 4. Students can improve their grammatical accuracy through frequent } \\
\text { practice of structures. }\end{array}$ & 4.38 & .603 \\
\hline $\begin{array}{l}\text { 5. Giving feedback and correcting errors are important for leaning } \\
\text { grammar. }\end{array}$ & 4.48 & .693 \\
\hline $\begin{array}{l}\text { Likert scale: 1 - Strongly Disagree; } 2 \text { - Disagree; 3 - Neutral; 4 - Agree; 5 - Strongly Agree } \\
\end{array}$
\end{tabular}

In terms of their classroom practices, the data in Table 5 shows a clear preference for a more traditional approach of explicit teaching of grammar where rules and sentence structures are first told to the students and brought to their attention, as seen in the teachers' responses to item 1 in Table 5 (mean 4.04). This preference clearly correlates with their set of beliefs on the importance of grammar rules seen in Table 4 . There is often a focus on both forms and meaning as demonstrated in their responses to item 2 in the table below. In terms of how grammar is taught, the teachers claimed that they often (mean of 3.88 as seen in Table 5) teach grammar in an integrated manner, where grammar is taught together with other language skills like speaking and writing.

Table 5. Teachers' practices related to the teaching of grammatical rules $(\mathrm{N}=81)$

\begin{tabular}{lcc}
\hline & Mean & SD \\
\hline $\begin{array}{l}\text { 1. I describe rules then provide examples when teaching grammar. } \\
\text { 2. I teach grammatical forms and meaning together. }\end{array}$ & 4.04 & .818 \\
\hline $\begin{array}{l}\text { 3. My lessons on grammar are integrated into other activities like } \\
\text { speaking and writing. }\end{array}$ & 3.88 & .671 \\
\hline
\end{tabular}
Likert scale: 1 - Never; 2 - Seldom; 3 - Sometimes; 4 - Often; 5 - Always

Separately, when the teachers were asked about the manner in which they taught and reinforced grammar concepts, and how they assessed student learning, 85\% claimed they often/always encouraged the students to recall what they had just learnt. To check for understanding, $86 \%$ said that they often/always 
got the students to complete worksheets, while only $45 \%$ often/always gave quizzes and tests. More interestingly, 99\% of the teachers indicated that they made it a point to always correct students' errors by giving them constant feedback.

Nonetheless, despite how much explicit grammar teaching had been carried out in the classroom, not only did students find grammar concepts difficult, but they were also not able to transfer their knowledge of grammar into communicative language use according to the teachers (refer to Table 6). In other words, some students still struggled with speaking and writing grammatically, as noted by the errors made in their productive use of the language.

Table 6. Students' abilities (N=81)

\begin{tabular}{|c|c|c|}
\hline & Mean & SD \\
\hline 1. My students find grammar terms and concepts difficult. & 3.41 & .669 \\
\hline $\begin{array}{l}\text { 2. My students can transfer their grammatical knowledge into } \\
\text { communicative language use. }\end{array}$ & 3.16 & .770 \\
\hline
\end{tabular}

Teachers were asked to rate their knowledge of grammatical rules, their sense of efficacy in explain difficult concepts to students, and their ability to respond to student questions. Based on their responses, teachers indicated that they could perform these tasks from 'fairly well' to 'well', with an overall mean of about 3.4 (refer to details in Table 7). They also seemed fairly confident in their ability to teach grammar concepts well.

Table 7. Efficacy for instructional strategies $(\mathrm{N}=81)$

\begin{tabular}{lcc}
\hline & Mean & SD \\
\hline $\begin{array}{l}\text { 1. I know the rule/s to explain why a particular sentence is } \\
\text { ungrammatical. }\end{array}$ & 3.54 & .635 \\
\hline $\begin{array}{l}\text { 2. I can explain difficult grammar concepts so that pupils can } \\
\text { understand. }\end{array}$ & 3.26 & .775 \\
\hline $\begin{array}{l}\text { 3. I can respond to pupils' questions on grammar that may have } \\
\text { more than one possible answer. }\end{array}$ & 3.41 & .791 \\
\hline 4. I am able to teach grammar concepts well. & 3.75 & .630 \\
\hline
\end{tabular}

Likert scale: 1 - Not well at all; 2 - Not too well; 3 - Fairly well; 4 - Well; 5 - Very well

Separately, when asked if they believed that 'Grammar focuses in form and meaning', 95\% of the teachers strongly agreed/agreed with the statement. A follow-up question of knowledge of verbs was posed to the teachers, and when asked how well they know the difference between verb forms and verb meanings, $73 \%$ indicated that they know the difference (very) well, as seen in Figure 1. 


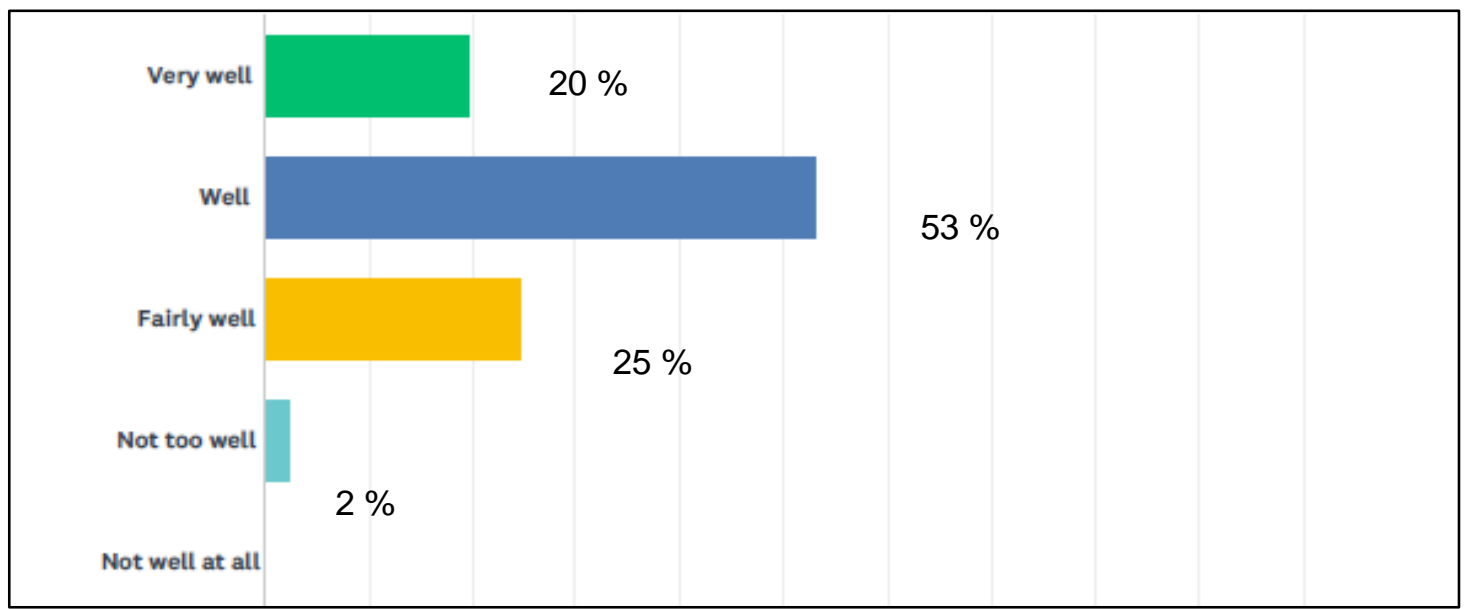

Figure 1. 'I know the difference in verb forms and meanings' $(\mathrm{N}=81)$

There was also a high degree of confidence among the teachers in their ability to explain when and why certain verb forms were needed in specific sentence structures. As shown in Figure 2, 73\% of them indicated they could do this (very) well.

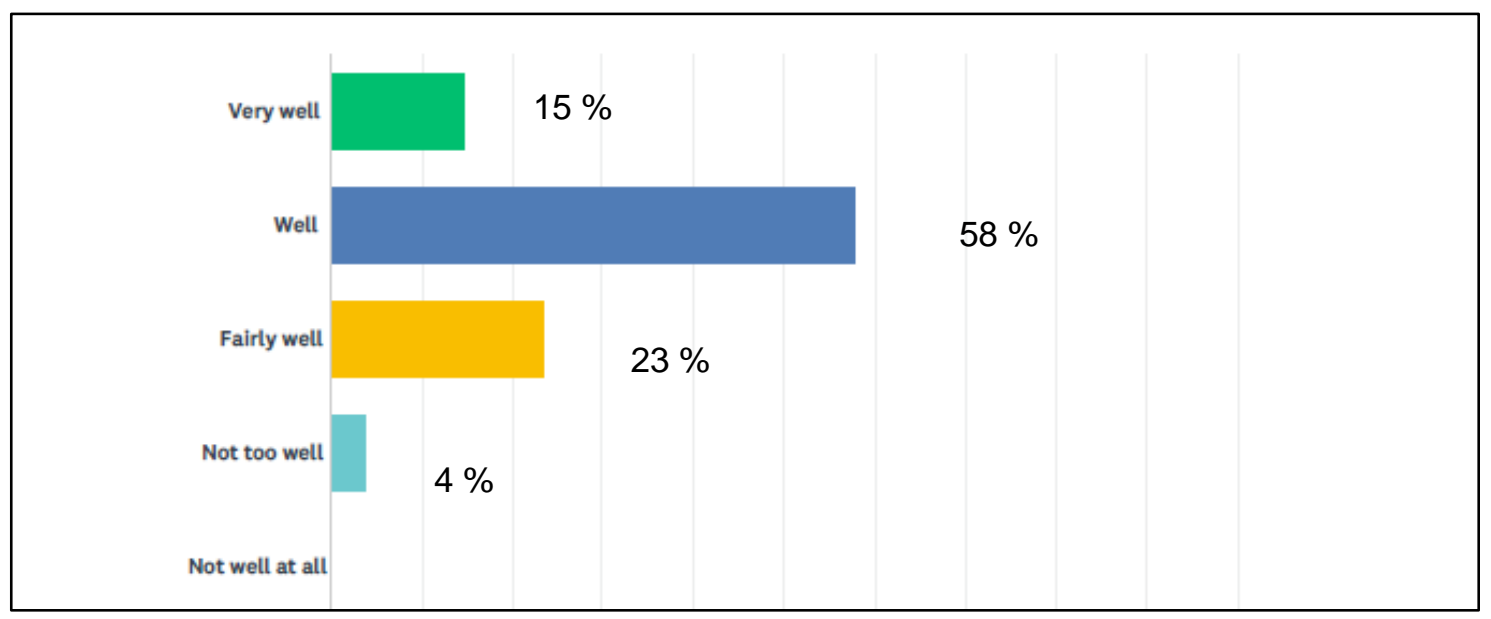

Figure 2. 'I can explain to students when/why they need to use a particular verb form.' ( $\mathrm{N}=81)$

\section{Challenges}

The teachers were also asked an open-ended question: "What are some of the challenges you face in planning and delivering a grammar lesson, and in assessing your students' understanding?"

Eight main concerns were identified:

Journal of English Language Teaching Innovations and Materials (JELTIM), 2(1), 1-13

Copyright ( 2020 by JELTIM, e-ISSN 2657-1617 
1. Varying students' abilities (46.3\%)

The teachers shared that the students they had came with varying linguistic abilities and knowledge of grammar. Some students "lack(ed) basic knowledge and terms on grammar" while others "might have acquired the wrong grammatical structures outside the classroom", making it "hard for them to unlearn and apply the correct structure." A few noted that the teaching of grammar was especially challenging with weaker students who found grammar "quite abstract".

2. Differentiated instruction $(22.5 \%)$

This is linked to the first challenge -- teachers mentioned that they found it difficult to provide differentiated instruction for students at different progress levels. As shared by one of the teachers: "Going down to the level of the young children. Bridging the gaps for non-native speakers e.g. children who do not speak the language at home." Teachers would like to know how best to explain certain grammatical rules to students of different abilities.

3. Engaging and interesting lessons (28.8\%)

Some teachers had difficulty engaging the students and had difficulty making grammar lessons interesting. Most of the teachers also commented that this might be due to the subject matter - that grammar, by itself, could be a 'dry' material.

4. Teachers' subject content knowledge (18.8\%)

Some teachers also indicated they lacked the necessary subject content knowledge to deliver their lessons well. As shared by one of the respondents: "(I) am not sure of some of the grammar rules myself. Sometimes searching on the net makes it even more confusing."

5. Availability of teaching resources (16.3\%)

They shared that they faced difficulties in finding authentic, relevant teaching resources. One shared that she could not find "appropriate examples to illustrate how the grammar item can be used in context."

6. Lack of time $(12.5 \%)$

A few teachers mentioned they either lacked the time to plan their lessons or lacked the time to deliver them.

7. Subject matter $(7.5 \%)$

Some of the teachers mentioned that the technicalities of some of the grammatical rules made the teaching of English grammar to primary school children very challenging. 


\section{Assessment $(5.0 \%)$}

It is interesting to note that very few teachers had identified assessment as a challenge. Only 5\% addressed concerns about assessing students' knowledge of grammar.

Based on the data presented thus far, it is evident that (i) teachers believe strongly in the importance of grammar instruction, and that (ii) teachers spend a fair amount of curriculum time to carry out explicit grammar teaching in their classrooms. However, based on the data, it has been shown that the teachers believed that students were not able to put their grammatical knowledge to communicative use despite extensive grammar teaching. In order to explain this 'failure' on the part of students, it is necessary to understand the type of grammar instruction that actually takes place in the classroom - the teaching materials adopted, the classroom activities, the teachers' approach/es and explanations. Future studies involving classroom observations need to be carried out to find out the teachers' actual classroom practices and check them against what teachers claim they do, and if the practices align with their stated beliefs.

It could be the case, as the data has shown, that teachers have a preference towards adopting a more traditional and deductive approach to grammar teaching with an emphasis on drill and practice, and not enough integrated activities where grammar instruction is woven into and explicitly linked to speaking, reading and writing activities. Perhaps there needs to be a more balanced approach to grammar instruction where grammar is also taught and understood implicitly through a variety of stimuli as well as exposure to a different spoken and written language use.

Another possible explanation for the disparity between grammar instruction and student learning might be due to the teachers' in/ability to explain these concepts well. In order to teach these grammatical concepts well, teachers need to have strong subject knowledge - they must not only know the rules, meaning and use of the grammatical concepts, they must also be able to present this at an appropriate level that their students can understand. Hence, a set of question was included in the survey to gauge how well teachers know their grammar.

Teachers were asked to rate their knowledge of grammatical rules, their sense of efficacy in explain difficult concepts to students, and their ability to respond to student questions. Based on their responses, teachers indicated that they could perform these tasks from 'fairly well' to 'well', with an overall mean of about 3.4 (refer to details in Table 8). They also seemed fairly confident in their ability to teach grammar concepts well. 
Table 8. Efficacy for instructional strategies $(\mathrm{N}=81)$

Mean SD

\begin{tabular}{|c|c|}
\hline $\begin{array}{l}\text { 1. I know the rule/s to explain why a particular sentence is } \\
\text { ungrammatical. }\end{array}$ & 3.54 \\
\hline $\begin{array}{l}\text { 2. I can explain difficult grammar concepts so that pupils can } \\
\text { understand. }\end{array}$ & 3.26 \\
\hline $\begin{array}{l}\text { 3. I can respond to pupils' questions on grammar that may have more } \\
\text { than one possible answer. }\end{array}$ & 3.41 \\
\hline 4. I am able to teach grammar concepts well. & 3.75 \\
\hline
\end{tabular}

Likert scale: 1 - Not well at all; 2 - Not too well; 3 - Fairly well; 4 - Well; 5 - Very well

The mean scores of below 4 consistently in Table 8 might suggest that overall, the teachers had some trouble with grammar, and faced some challenges in explaining these concepts to their students clearly, resulting in their students lack of ability to use the grammar concepts accurately in their writing.

\section{CONCLUSION}

This study has not only identified teachers' beliefs on grammar instruction, it has also provided insights on the influence of those beliefs on instructional practices. Based on the research findings, there is generally a strong correlation between teachers' beliefs on grammar/grammar instruction and their (self-reported) classroom practices. Future studies involving lesson observations would also help the researcher understand why despite the amount of explicit teaching of grammar in the Singapore primary classrooms, teachers found that students still faced difficulties in using the grammatical items well in their individual writing and in their classwork.

According to Johnson (1994), understanding teachers' beliefs is crucial to improving teachers' classroom practices and teacher education programs. Hence, it is hoped that the findings from this small-scale quantitative study will help inform pre-service and in-service programmes offered at and by the National Institute of Education (Singapore), content developers, and policy makers in developing appropriate training and teaching resources for teachers. Future training could perhaps try to address some of the challenges articulated by the teachers, especially in helping them develop effective lessons to cater to the differing needs and abilities of their students, and in creating more engaging grammar lessons. 


\section{REFERENCES}

Aljohani, S.M.A. (2012). Grammar beliefs of in-service teachers. British Journal of Arts and Social Sciences, 11(1): 96-108.

Aman, N. (2016). "I believe, therefore I practice": Teachers' beliefs on literacy acquisition and their classroom practices. In Silver, R., \& Bokhorst-Heng, W. (Eds.), Quadrilingual Education in Singapore: Pedagogical innovation in language education (pp. 39-56). USA: Springer.

Borg, S. (2003) Teacher cognition in grammar teaching: A literature review. Language Awareness, 12(2): 96-108.

Canh, L. V., \& Barnard, R. (2009). Teaching grammar: A survey of teachers' attitudes in Vietnam. The Journal of Asia TEFL, 6(3): 245-273.

Chia, S. C. C. (2003). Singapore primary school teachers ${ }^{\text {ee }}$ beliefs in grammar teaching and learning. In D. Deterding, A. Brown \& E. L. Low (Eds), English in Singapore: Research on grammar (pp. 117-127). Singapore: McGraw Hill.

Farrell, T.S. C., \& Lim, P.L.P. (2005). Conceptions of grammar teaching: A case study of teachers' beliefs and classroom practices. The Electronic Journal for English as a Second Language, 9(2) : 1-6.

Johnson, K. E. (1994). The emerging beliefs and instructional practices of preservice English as second language teachers. Teaching and Teacher Education, 10(4), 439-452.

Kagan, D. (1992). Implications of research on teacher belief. Educational Psychologist, 27, 65-90.

McMullen, M.B. (1999). Characteristics of teachers who talk the DAP talk AND walk the DAP walk. Journal of Research in Childhood Education, 13(2), 216230.

Ng, E. K. J., \& Farrell, T.S.C. (2003). Do teachers' beliefs of grammar teaching match their classroom practices? A Singapore case study. In D. Deterding. Brown A \& Low E L (Eds. 2003) English in Singapore: Research on Grammar. Singapore (pp. 128-137): McGraw Hill.

Ng, C. H. (2012). Teacher cognition and grammar teaching approaches. Southeast Asia: A Multidisciplinary Journal, 12: 17-31.

Orton, R. E. 1996 How can teacher beliefs about student learning be justified? Curriculum Inquiry 26(2), 203-217.

Pajares, M.F. (1992). Teachers' beliefs and educational research: Cleaning up a messy construct. Review of Educational Research, 62(3), 307-332. 
Richardson, V., Anders, P., Tidwell, D. \& Lloyd, C. (1991). The relationship between teachers' beliefs and practices in reading comprehension instruction. American Educational Research Journal, 28(3), 559-584.

Vartuli, S. (1999). How early childhood teacher beliefs vary across grade level. Early Childhood Research Quarterly, 14, 489-514.

\section{Author's Brief CV}

Norhaida is a Senior Lecturer at the National Institute of Education, Singapore. She has published in the area of the teaching and learning of English grammar; sociolinguistic issues like bilingualism, language and identity; as well as matters that relate to teacher education like the relationship between teacher beliefs and practices. 